\title{
TURKS AND THEIR TRANSLATIONS/ COMMENTARIES ON THE QUR'ÂN: AN HISTORICAL AND BIBLIOGRAPHICAL SURVEY
}

TÜRKLER VE KUR'ÂN TERCÜME VE TEFSIRLERI: TARIHÎ VE BIBLIYOGRAFIK BIR INCELEME

\author{
HALIL SIMSSEK \\ DR., BAḠIMSIZ ARASTIRMACI, \\ DR., INDEPENDENT RESEARCHER \\ hllsmsk@gmail.com \\ (iD) https://orcid.org/0000-0002-3990-1071 \\ doi http://dx.doi.org/10.29228/k7auifd.15
}

Makale Bilgisi / Article Information

Makale Türü / Article Types

Araștırma Makalesi / Research Article

Geliș Tarihi / Received

21 Temmuz / July 2019

Kabul Tarihi / Accepted

18 Aralık / December 2019

Yayın Tarihi / Published

Aralık / December 2019

Yayın Sezonu / Pub Date Season

Aralık / December

Atıf / Cite as

Simsek, Halil, “Turks and Their Translations/Commentaries on the Qur'ân: an

Historical and Bibliographical Survey [Türkler ve Kur'ân Tercüme ve Tefsirleri: Tarihî ve Bibliyografik Bir İnceleme]". Kilis 7 Aralık Üniversitesi İlahiyat Fakültesi Dergisi Journal of the Faculty of Theology 6/11 (Aralık/December 2019): 395-420.

Intihal / Plagiarism: Bu makale, en az iki hakem tarafından incelendi ve intihal içermediḡi teyit edildi. / This article has been reviewed by at least two referees and scanned via a plagiarism software.

Copyright (C Published by Kilis 7 Aralık Üniversitesi, İlahiyat Fakültesi - Kilis 7 Aralık University, Faculty of Theology, Kilis, 79000 Turkey. All rights reserved.

For Permissions

ilahiyatdergisi@kilis.edu.tr 


\title{
TURKS AND THEIR TRANSLATIONS/COMMENTARIES ON THE QUR'ĀN: AN HISTORICAL AND BIBLIOGRAPHICAL SURVEY
}

\begin{abstract}
In this study, we have provided an analysis of fort he translations and exegetical works of the Qurān in Turkic, Old Anatolian,and/or Ottoman dialects. We have striven to provide an account of a heritage that has been the subject of study in several articles and monographs. Our study surveys the pre-Saljuqid and pre-Ottoman eras, as well as the Saljuqid and Ottoman eras. We have presented the current status of survey on what has become known as the heritage of "Eastern Turkic Translations of the Qur'ann" coupled with commentary-like activities of the pre-Saljuqid and Ottoman eras, and added our own comments and observations. We then followed our survey with the heritage of Ottoman era for the translations and commentaries of the Qur'ān. We hope to have contributed in the sense that there are several ambiguities and unknowns with respect to non-Arabic Qur'ān studies of the medieval era, and our survey may very well be considered to have provided some insight and new observations in the field of Quranic studies.
\end{abstract}

\section{Summary}

The following survey article concerns the study of the translations in Turkic languages of the Qur'ān and Qur'anic exegesis in light of the modern research articles that have been produced by the Islamicists and Turcologists alike. We have limited the scope of our research to the to the translation activities in Turkic languages that were produced in one of the following eras in the history of Turks: Central Asian period, the Saljuqid and pre-Ottoman period, and the Ottoman period. We have, however, also noted that the translation activities of religious texts can be dated back to the pre-Islamic Turkic period as well.

Current research has so far been able to ascertain that the earliest Turkish-Muslim literature is the $11^{\text {th }}$ century Kutadgu Bilig of Yūsuf Khāṣṣ Haajib and the earliest surviving copies of the translations of Quran and exegesis-like literature date back to a period between the $12^{\text {th }}-16^{\text {th }}$ centuries. Based on these data, various researchers have proposed theories about how and when these translations were undertaken, and on what kind of sources or tradition they drew. The fact that the Qur'anic exegesis of al-T Tabarì by a committee under the patronage of the Samanid dynasty and the fact that Bal'amī summarized this translation and produced an interlinear Qurān translation in Persian in the $10^{\text {th }}$ century informed the majority of the theories formulated in this context. Based on the preceding and, additionally, on the comparative textual study of the Turkic and Persian translations, Z. Velidi Togan argued that the surviving translation copies of the $12^{\text {th }}-16^{\text {th }}$ centuries drew on a now lost copy that must have dated back to the $10^{\text {th }}$ century and must have been produced in tandem with the translation of al-Ṭabarîs exegesis. He also added that since some of the members of the translation committee included scholars from central Asian regions mostly inhabited by people of Turkic stock, it stands to reason that a translation in Turkic dialect was also produced contemporaneously. Furthermore, Togan reasoned, the Samanids needed a translated text of the Qur'an for the purpose of proselytizing the people of Turkic stock and it behooves us to presume that a now lost copy of a Qur'an translated into Turkic dialect was produced in the $10^{\text {th }}$ century. Janos Eckmann, by comparison, textually and comparatively studied the surviving translations and demonstrated that they form two distinct categories: interlinear word-by-word translations of the Arabic text of the Qur'an whose provenance can be ascertained as the Qarakhanid era, and the commentary-like translations of the Qur'ann that belong to the Khorezmian and Chaghatayid era and dialects. 
Some studies focused on specific surviving copies of the Qurān and exegetic translations have presented results that somehow bolstered the theories advanced by Togan. Also known as the "Anonymous", the Leningrad copy is presumed to have drawn on a non-extant copy that must have been produced in the $10^{\text {th }}$ century and under the Samanid dynasty. The T73 copy, preserved in the Museum of Turkish and Islamic Works, is taken to have drawn on an original that is now lost but must have dated back to the $11^{\text {th }}$ century. And last, but not the least, Abdülkadir İnan posited that the interlinear translation copy preserved in the Hekimoğlu Ali Paşa Camii no. 2 must have drawn on an original copy that is older than the aforementioned Leningrad copy and that which must have belonged to the $10^{\text {th }}$ century.

Although the translation activities of the Qur'ān and Qur'anic exegesis continued during the Anatolian Saljuqid and pre-Ottoman Anatolian principalities period, these were limited to individual Qur'anic chapters, and the complete translations of the Quranic exegetical works in Anatolian and Old Ottoman Turkish began to be produced only the by the turn of the $15^{\text {th }}$ century. Perhaps the earliest such translation was the translation of the Qur'anic exegesis of Abū al-Layth al-Samarqandì. Our sources indicate that this translation was undertaken by three distinct figures and modern research is mired in ambiguities about the verity of the date presented by these sources. Our own research led us to determine that this translation was most likely undertaken by Ạ̣mad-i Dā'ī, and that the copies attributed to Mūsā İznikī and Ibn Arabshāh were the result of mistakes committed either by our sources and/ or library catalogers. However, we have also noted our preservation that the probability of different Anatolian princes commissioning different scholars to translate the same and particular scholarly and religious works cannot be excluded.

We have also critically and analytically examined the various theories advanced for the provenance and sources of the Turkish/Ottoman exegetical endeavors. In addition to the theory advanced by İnan that the Turkish and Ottoman exegesis was informed by a "Central Asian Tradition", Gunasti argued that it respectively drew on a "Samarqandī" tradition, was later supplanted by the Zamakhsharian tradition which in turn was ultimately replaced by the Bayḍāwī influence. We have observed that neither İnan's theory nor that of Gunasti provides a satisfactory elaboration on the specifics and details of what their theories may entail. Our study also covers a number of exegetical translations produced especially during the $16^{\text {th }}-19^{\text {th }}$ century Ottoman era and, at the same time, attempts to touch upon some of the masterpieces of Ottoman exegetical heritage for the purpose of drawing to attention that the field remains fairly uncharted.

Even though this research may at the first look seem to have been imprinted with only the analytical and critical assessment of the recent surveys, careful and close reading will reveal newer and different approaches and theories on the topic, and, at the same time, will point to the aspects and issues that await further research.

Keywords: Commentary, Turkic translations of the Qurān, Ottoman translations of the Qurān, Ottoman Qur'anic commentaries, Quranic Studies, Ottoman tafsìr tradition.

\section{TÜRKLER VE KUR'ÂN TERCÜME VE TEFSİRLERİ: TARİHÎ VE BİBLIYYOGRAFİK BİR İNCELEME \\ Öz}

Burada sunduğumuz araştırmamız Türklerin ve Türkî toplumların Kur’an tercümeleri ve Kur'an tefsirleri ve tercümeleri alanında ortaya koymuş oldukları Türkī lehçelerdeki, Anadolu ve Osmanlı Türkçesi dillerindeki, ve yüzeysel de olsa Osmanlılar tarafından telif edilen bazı Arapça tefsir çalışmaların tarihsel ve bibliyografik bir 
incelemesini vermektedir. Çalışmamızda Türklerin İslamla müşerref olmalarından başlayarak orta Asya coğrafi bölgesinde Türkî dillerle yapılan tercüme faliyetleri ele alınmış, Selçuklular dönemindeki çalışmaların seyri ve sonrasında da Anadolu Türkçesi ve Osmanlı Türkçesi ile yapılan tercüme ve tefsir çalışmalarının bibliyografik incelemesi bu konularda yapılan modern araştırmalar ışığında irdelenmiş ve mevcut tezlere kendi değerlendirmelerimiz ve gözlemlerimiz de eklenmiştir. Özellikle Osmanlı ilim adamları tarafından telif edilen hem tefsir tercümeleri hem de müstakil tefsir telifleri dikkate alınarak yapılan modern araştırmaların analitik ve tenkitçi süzgeçten mahrum olduğu gözlemlenmiştir. Bu ve benzeri gözlemlerimize binaen, yeni araştırmalar için henüz yayınlanmamış bir çok eserin yeni araştırmacıları beklediği, ve diğer taraftan da bibliyografik envanterin revize edilmesi ve güncellenmesi babında eksikler olduğu kanaati hasıl olmuştur.

\section{Özet}

$\mathrm{Bu}$ araştırma makalesi hem İslam araştırmaları hem de Türk dünyası araştırmalarının ilgi alanına giren Türklerin Kurân ve Kur’ân tefsiri çalışmalarını özellikle son zamanlarda yapılan modern araştırmalar ışığında incelemektedir. Çalışmamız Türklerin Kur'ân tercümeleri ve Kur'ân tefsiri tercümeleri, Orta Asya Türk mirası, Selçuklu ve Osmanlı öncesi miras, ve Osmanlı mirası evreleri ile sınırlandırılmıştır. Türklerin İslamla müşerref olmadan önce de kutsal ve dini metinleri tercüme faaliyetleri not edilmiş, ve bu tür tercüme geleneğinin en erken dönemlerde de vuku bulduğu tespit edilmiştir.

Türk-İslam edebiyatı geleneğinde günümüze ulaşan en erken eser 11. yüzyıl müelliflerinden Yusuf Has Hacib tarafından kaleme alınan Kutadgu Bilig olması hasebiyle ve gene günümüze kadar ulaşan en erken Türk dillerinde tercüme edilen Kurân kopyalarının 12-16. yüzyıllara raci olmasına binaen bir takım araştırmalar bu tercüme faaliyetlerinin tam olarak ne zaman başladığı, hangi ve ne tür bir kaynak ve gelenekten beslendiği, ve/veya hangi döneme ait eserlerin bir neticesi olduğu yönünde teoriler ortaya koymuşlardır. 10. yüzyıl Orta Asya beyliklerinden Samanoğulları’nın himayesi altında kurulan bir komisyon tarafından tercüme edilen Taberi tefsiri ve Bel’ami tarafından bu tercümenin kısaltılarak satırarası bir Kurân tercümesinin ortaya konması neticesinde modern dönem araştırmaları değişik tezler öne sürmüşlerdir. Zeki Velidi Togan günümüze ulaşan bir kopyası olmasa da, 12-16. yüzyıllardan günümüze ulaşan eserlerin kaynağını teşkil eden ve Taberi’nin tefsirinin tercümesi ile paralel zamanda tercüme edilen Türkî dilde bir Kurân tercümesinin yapılmış olduğunu öngörmüş, ve bu tercüme faaliyetinin Fârisî gelenekten etkilendiğini iddia etmiştir. Togan tezlerini ispat sadedinde Türkçe ve Farsça tercümelerin mukayeseli çalışmasını yapmış, Taberi’nin tefsirini tercüme eden komisyonda Türklerin yoğunlukta yaşadığı bölgelerden de ilim adamlarının bulunduğunu savunmuş, Samanoğulları’nın Türkleri İslam’a davet etmek için Türkî dilde bir Kurân tercümesini yaptırmış olabileceği ihtimalini göz önünde bulundurmuştur.

Türklerin Kur'ân, tefsir, ve bunların tercümeleri alanında Orta Asya Turkî gelenek olarak isimlendirilen bu eserler muhteva açısından da farklılık arzetmektedir. $\mathrm{Bu}$ bağlamda Janos Eckmann bu girişimleri satırarası kelime tercümeleri ve tefsiri andıran kısa açıklamaları ihtiva eden tercümeler olarak iki sınıfa işaret etmiştir. Aynı yazar bu tercümeleri incelemesi neticesinde satırarası tercümelerin Karahanlılar dönemine ait olduğunu, diğer sınıfın ise Harezm ve/veya Çağatay dönemine ait olduğunu iddia etmiştir. Şu anda Leningrad'da mahfuz tutulan ve "Anonim kopya" olarak bilinen yazarı meçhul tercümenin metinsel özelliklerinden hareket eden bazı araştırmacılar bu tercümenin Samanoğulları döneminde kaleme alınan ama şu anda kayıp olan bir orijinal tercümeye dayandığını öne sürmüşler ve böylece Togan’n tezlerini destekler mahiyette görüş belirtmişlerdir. Diğer taraftan, 1330 tarihinde 
istinsah edilen ve Türk İslam Eserleri Müzesinde bulunan T73 kayıtlı Kur'ân tercümesi de modern araştırmalara konu olmuş, kimi araştırmacılar metinsel analizleri neticesinde bu tercümenin de 11. yüzyılda yazılan ama günümüze ulaşmayan bir orijinal metne dayandığını öne sürmüşlerdir. Hekimoğlu Ali Paşa Camii, no. 2 kaydıyla mahfuz başka bir satırarası tercüme üzerinde incelemeler yapan Abdülkadir İnan bu tercümenin Leningrad'da mahfuz anonim kopyadan daha eski fakat günümüze ulaşmayan bir kaynak tercümeye istinat ettiği kanaatini dillendirmiş olsa da, daha somut delillerin ortaya çıkması yönünde yeni araştırmalara teşvik etmiştir.

Modern araştırmalar neticesinde Anadolu Selçukluları döneminde Türkçe Kurân ve tefsir tercümelerine rastlanmazken, Anadolu beylikleri döneminde müşahade edilmiş ama aynı zamanda bu tercüme faaliyetlerinin Kurânı̉ı tamamına değil muayyen surelerine inhisar ettiği ortaya konmuştur. Anadolu Türkçesi ile Kur’ân’n tamamına müştemil tefsirler ve/veya tercümeler 15. yüzyıldan sonra kaleme alınmaya başlamıştır. Bu bağlamda tercüme edilen ilk tefsir belki de Ebü'l-Leys esSemerḳandînin tefsiridir. Kaynaklar ve mevcut el yazmaları bu tefsirin üç değişik şahsiyet tarafından tercüme edildiğini kaydetmekte, bu durum modern araştırmac1lar için zihin karışıklığına sebep olmaktadır. Kesin olarak belirtme şansımız olmasa da, biz bu araştırmamızla bir el yazmasını nüshasını da incelediğimiz bu tercümenin aslında Aḥmed-i Dāīi tarafından yapıldığını, Mûsâ İznikî ve İbn Arabşah’a atfedilen tercümelerin ise kütüphane kayıtlarındaki ve kaynak verilerindeki hatalardan kaynaklandığını ortaya koymaya çalıştık. Buna rağmen, tefsirin tercüme edildiği 15. yüzyıl siyasi şartları da göz önüne alındığında, aynı tefsirin muhtelif Anadolu beyleri tarafından farklı kişilere tercüme ettirilmiş olabileceği ihtimalinin de geçerli olabileceğini savunduk.

Eldeki veriler muvacehesinde yapılan modern araştırmalar Türklerde Kur'ân tercüme ve tefsirinin etkilendiği kaynak ve gelenek de incelenmiş, bu konuda ortaya konan tezler tenkitçi bir süzgeçten geçirilmiştir. Abdülkadir İnan bu tür çalışmaları "Orta Asya Geleneği”"ne dayandırmış, fakat bu geleneğin özellikleri hakkında açıklama ve ayrıntı vermemiştir. Gene aynı şekilde, Türklerde Kur’ân ve tefsir tercümelerinin "Semerkandî" gelenekten etkilendiğini ifade eden Susan Gunasti bu etiketlemenin coğrafi mi yoksa öznel mi olduğu ve/veya ne tür özellikler ihtiva ettiği yönünde bir açıklama yapmamıştır. 15. yüzyılda yazıldığı tespit edilen ve kısa tefsir içerikli açıklamalar ihtiva eden iki tercüme Ahmet Topaloğlu tarafından incelenmiş ama bu tercümelerin kaynakları ve/veya istinat ettikleri gelenekler konusunda bir açıklama ortaya konmamıștır.

Elimizdeki veriler, Osmanlılar döneminde Türkçe tefsir ve tercüme faaliyetlerinin 16-19. yüzyıllarda da devam ettiğine işaret etmekte, fakat bu girişimlerin daha önce telif edilen Arapça ve/veya Farsça tefsirlerin tercümeleri olduğunu göstermektedir. Çalışmamız bu tercümelerin bazılarını kısaca incelemekte, ve özellikle Arapça telif edilen ve Osmanlı uleması tarafından yazılan tefsirlerin önde gelenlerinden hareketle Osmanlı tefsir geleneğinin kaynaklarına kısaca işaret etmektedir.

Çalışmamız genel olarak mevcut modern araştırmaların tenkitçi bir süzgeçten geçirilmesi izlenimi verse de, yer yer farklı mülahazalarımızı okuyucularımızın incelemesine sunmakta ve bu araştırma konusunda daha detaylı çalışmaların yapılması gereken yönlerine ve meselelerine işaret etmekteyiz.

Anahtar kelimeler: Tefsir, Türkçe Kur'an tercümeleri, Türkçe tefsir tercümeleri, Osmanlı tefsir mirası, Türkler ve Kur’an, Osmanlı müfessirleri, Türk müfessirleri. 


\section{INTRODUCTION}

ince the history of the Turkic people who embraced Islam as their

C religion geographically extends from the Far East to some of the Balkan states of today, it is rather a daunting task to trace comprehensively their literature in the interpretation of the Qurān. Our goal here is to present a biographical and bibliographical survey of some of the firsts and important works which seem to have been the subject of study in recent decades by both the Islamicists and the Turcologists alike. An exhaustive list of all surviving manuscripts and published works in the subject has been attempted by various authors. ${ }^{1}$ However, as has been asserted by several modern researchers, a greater bulk of these works tends to replicate earlier works and lacks any significant originality. ${ }^{2}$

Any attempt to survey the Turkic tradition of the Quranic interpretation should consider the fact that the Turks consisted of several different tribes, and while some of them constantly migrated westward and established various dynasties and principalities along the way until the last Mongol pressure during the mid-thirteen century, some others settled in the regions of central Asia. Therefore, it is essential to sketch this survey in three parts; Eastern Turkic tradition; Saljuqid and pre-Ottoman tradition; and Ottoman tradition until the establishment of modern Turkish Republic in 1923. Excluding the republican era should in no way mean lack or scarcity of the tradition of Quranic interpretations during this time, however, due to complexities therein and the lack of space herein we preferred to defer it to another occasion. ${ }^{3}$

Interpretation of religious literature in general and religious scriptures in particular by the Turks could be dated as far back as the advent of universal religions within their regions. Buddhism, Zoroastrianism, Manichaeism, and Christianity are the religions with which the Turks came into contact, thanks to their changing geographical locations along the major

\footnotetext{
1 See, for example, Macit Yaşaroğlu, Kur'an-ı Kerim'in Türkçe terceme ve tefsirlerinin kronolojik bibliyografisi, published in tandem with Muhammed Hamidullah, Kur'an-ı Kerim tarihi (Bir deneme). (Ankara: Diyanet İşleri Baskanlığı Yayınları, 1991). The latter gives a list of 118 works that consists of both manuscripts and published literature in Uyghur, Arabic and Latin scripts, whereas the former provides a list of 75 works in manuscript and published form. Both lists include the modern Turkish republican era.

2 Hidayet Aydar, “Türkler’de Kur’an çalışmaları” Istanbul Üniversitesi İlahiyat Fakültesi Dergisi 1 (1999), 159-235.

3 For a recent study on the Republican era, however, see, M. Brett Wilson, "The Qur'ān After Babel: Translating and Printing the Qurān in Late Ottoman and Modern Turkey” (South Caroline: Duke University, Unpublished PhD dissertation, 2009).
} 
trade routes. Documentary evidence indicates that the Turks, before they embraced Islam, had translated Buddhist, Manichaeist and Christian religious texts and that much of the Islamo-Turkic vocabulary of the day can be traced back to those translations. ${ }^{4}$

\section{THE EARLIEST ATTEMPTS AND THE EASTERN TURKIC TRANSLATIONS}

The wholesale conversion of Turks to Islam is traditionally dated back to the early second half of the $10^{\text {th }}$ century $\mathrm{CE}$, probably just before the first written translation of al-Ṭabarīs (d. 923) commentary into Persian during the Samānid ruler Manșūr Ibn Nūh (r. 961-976) in Transoxania was produced. By the turn of the $11^{\text {th }}$ century, the whole region beyond the river Oxus would become under the suzerainty of the Qarakhānid Turks, by whom the earliest Islamo-Turkic religious literature was produced, namely the Kutadgu Bilig of Yūsuf al-Khaṣs Haajib (d. 1075). Abdulkadir Inan thinks that the first translations of the Qurān must have been produced during these times, namely the first half of the $11^{\text {th }}$ century. ${ }^{5}$ He also believes that the extant copies of the earliest Eastern Turkic translations of the Qur'ān which are copied during the early $14^{\text {th }}$ century must have drawn on an earlier original that belonged to the $11^{\text {th }}$ century. ${ }^{6}$ By contrast, Zeki Velidi Togan argues that the earliest translation of the Qur'an can be dated as far back as the second half of the $10^{\text {th }}$ century, contemporaneous with the Persian translation of al-Tabarīs commentary. ${ }^{7}$ Eleazar Birnbaum notes that Bal'amī, the head of the translation committee for al-Tabarì's commentary, abridged al-Ṭabarîs commentary and provided an interlinear rendering in Persian beneath the Arabic text of the Qurān, and this interlinear translation of the Qur'ān was later followed by numerous other such works in Persian and Turkish alike. ${ }^{8}$ Togan based his argument: first on the fact that the committee of al-Tabarîs translation included scholars from the regions of Farghāna, Isfijjāb, and others which were mainly inhabited by Turks, and it follows that it was only normal that the Qurān

4 Abdulkadir İnan, Kur’an-ı Kerim’in Türkçe tercemeleri üzerinde bir inceleme. (Ankara: Türk Tarih Kurumu Basımevi, 1961), 3-5.

5 İnan, Bir İnceleme. 8

6 İnan, Bir İnceleme, 8.

7 Zeki Velidi Togan, “The Earliest Translation of the Qurān into Turkish” İslam Tetkikleri Enstitüsü Dergisi, Istanbul University, Publications of the Faculty of Letters, issue 4, (1964), 18.

8 Eleazar Birnbaum, “On Some Turkish Interlinear Translation of the Qur'ann” Journal of Turkish Studies, Türklük Bilgisi Arastirmalari 14, Fahir Iz Armağanı, Fahir Iz Festschrift 1 (1990), 113. 
was also translated into Turkish along with the Persian translation. ${ }^{9}$ Secondly, Togan conducted a comparative textual survey between the earliest Persian translations, which inarguably depended on al-Tabarì's translation, and the earliest extant copies of the Turkish translations, and attempted to demonstrate the similarities between the two translations. ${ }^{10}$ Furthermore, Togan also argued that the Samānids must have had means of propaganda for Islam among the Turks, who constituted the greater bulk of the military power of their kingdom, and one of these means was most likely a Turkish translation of the Qur'ān not only in Arabic script but probably in Uighur and Kök-Turkic scripts as well. ${ }^{11}$

What must be noticed in this argumentation is the implication that the Turks translated the Qur'ān, not the commentary of al-Ṭabarī, and their translation was not based on the Arabic text but, as was demonstrated by Togan's comparative textual study, on the Persian translation of the Arabic text. Togan's assumptions, however strong they may be, remain unsupported by any concrete evidence until further research reveals otherwise. On the other hand, one must assume that the parts and the verses of the Qurān must have been rendered into Turkish at least orally during the $10^{\text {th }}$ century and/or even earlier before any written translation of the whole Qur'ān into Qarakhānid Turkish was produced. ${ }^{12}$ It must also be noted that the translations of individual Qur'anic verses are found in Kutadgu Bilig, a didactic poem written in 1069 by Yūsuf Khāṣs Hājib. ${ }^{13}$

The Qur'anic translations that are produced in Central Asiatic regions by the Turkic people are commonly categorized as the Eastern Turkic translations and there are probably at least six extant copies of these translations which were produced in the $12^{\text {th }}-16^{\text {th }}$ centuries. ${ }^{14}$ The Eastern Turkic translations seem to be modelled on the earlier Persian Translations of the Qur'ān and are essentially of two types: Interlinear translation and commentated translation. ${ }^{15}$ While the interlinear translations are the translation of the Qur'anic words along with the Arabic text, commentated translations are commentary-like explanations and added stories pertinent to

9 Togan, "The Earliest Translations", 8.

10 Togan, "The Earliest Translations", 4-13.

11 Togan, "The Earliest Translations", 16.

12 Birnbaum, “On Some Turkish Interlinear Translations”, 113.

13 Birnbaum, "On Some Turkish Interlinear Translations", 113.

14 Janos Eckmann, "Eastern Turkic Translations of the Qurān”, Studia Turcica, Bibliotheca Orientalis Hungarica 17, (Budapest: b.y., 1971),149-159, 151.

15 Birnbaum, "On Some Turkish Interlinear translations" 113; Also, Eckmann, "Eastern Turkic Translations", 151. 
the translated portion of the Arabic text. ${ }^{16}$ Janos Eckmann noted the difference between the literal interlinear translation and the commentated translation, and concluded that the latter was in Khorezmian Turkish and the former was in Qarakhānid Turkish. ${ }^{17}$ The fact that the commentated translation also included Chaghatāyid linguistic elements should indicate that this copy cannot be dated to earlier than the $15^{\text {th }}$ century. ${ }^{18}$ Inan mentioned another difference between the two and stated that the interlinear translation is linguistically older and more Turkic to the degree that non-Turkic words are very scarce, whereas in the commentated translation there is an increasing tendency toward Arabic and Persian words. ${ }^{19}$

One of the earliest translations in this category is probably the one that was discovered in 1914 in Uzbakistān by Zeki Velidi Togan and is preserved in the Institute of the Peoples of Asia in Leningrad. ${ }^{20}$ Also known as "the Anonymous" or "Central Asiatic Commentary", this translation was written down, according to Wilhelm Barthold, in Transoxania ${ }^{21}$ and/or, according to İnan, in Khorezm. ${ }^{22}$ The manuscript is not a complete version and chapters 1-19 and 23-48 are missing. ${ }^{23}$ Barthold suggested that this translation/commentary belonged to the earliest era of classical commentary tradition in that it draws on such lost works of Muhy al-Dīn b. al-Sāib alKalbī (d.146/764), and Ibn Isḥāq’s biography of the prophet Muhammad, the writings of Ibn Durayd (d. 321/933), and the sufi sayings of Ibrāhīm Ibn Adham (d. c. 165/782) which implies that the author was also acquainted with sufi literature. ${ }^{24}$ Barthold further noted that the commentary-like stories are presented as narrated by earlier reporters such as Ibn 'Abbās (d. 68/688), Ḥasan al-Bașrī (d. 110/728), Muqātil b. Sulaymān (d. 150/767), and Qatāda (d. 117/735), without later additions. ${ }^{25}$ The dean of Ottoman studies during the early $20^{\text {th }}$ century Mehmed Fuad Köprülü stated that the philological study of the text presented all sorts of complexities and the vocabulary as a whole was heterogeneous, and archaic words are at times exchanged with later vocabulary, which in the end indicated, he argued, a

\footnotetext{
16 Birnbaum, "On Some Turkish Translations" 114; and Eckmann, "Eastern Turkic Translations”, 151.

17 Eckmann, "Eastern Turkic Translations", 156.

18 Eckmann, "Eastern Turkic Translations", 156.

19 İnan, Bir inceleme, 10.

20 Eckmann, "Eastern Turkic Translations", 156.

${ }^{21}$ W. Barthold, "Orta Asyada İslamiyet'in intişar ettiği zamana ait bir abide” Türkiyat Mecmuası, Publications of the Turkish Institution at the Faculty of Arts in Istanbul University, (1928), 69-74, 69.

22 İnan, Bir inceleme, 9-11.

23 Eckmann, "Eastern Turkic Translations”, 156.

24 Barthold, "Orta Asya'da İslamiyet", 72-74.

25 Barthold, "Orta Asya'da İslamiyet”, 72-74.
} 
process of producing several copies at the hands of various people. ${ }^{26}$ In a separate article, Barthold also expressed his opinion about the time of an original copy on which the Leningrad manuscript drew as an earlier time than the $11^{\text {th }}$ century, and accepted it as the monument of the dynasty of the Samānids. ${ }^{27}$ Therefore, not only does Barthold agree with Togan who also posited that all the interlinear translations drew on a now-lost original copy which was produced during the time of Samānids simultaneously with the Persian translation of al-Tabarî's commentary, but he also concludes that the interlinear translation of the Leningrad manuscript is a later replica of that original copy.

Another Eastern Turkic translation of the Qur'ann has come down to us in a manuscript preserved in the Museum for Turkish and Islamic Works (Türk İslam Eserleri Müzesi) in Istanbul as no: T 73. It is a complete translation of the Qur'ān, and, according to its colophon, it can be dated to the 1330s. This copy is attributed to a copyist named Muhammad b. Hājī Dawlatshāh of Shīrāz. ${ }^{28}$ Inan also mentioned this manuscript and noted the similarities between this copy and the Anonymous commentary to the degree that chapters 18 and 19, al-Kahf and Maryam, are almost identical. Based on the foregoing, Inan concluded that the two drew on an earlier copy. ${ }^{29}$ This translation is a word by word interlinear translation of the Qur'ān and does not contain any commentary-like notes. ${ }^{30}$ The language of this translation is archaic and can be dated to $12^{\text {th }}$ or $13^{\text {th }}$ century Turkic literary language of the Qarakhānids in Islamic Central Asia. ${ }^{31}$ However, a textual study of this manuscript yielded the result that some parts were written in a later dialect, which was explained by Eckmann as that the parts that were written in the original dialect were missing and translated anew by either the copyist himself or someone else at around the $14^{\text {th }}$ century. ${ }^{32}$ Eckmann further argued that the original copy on which this translation drew was probably written in the second half of the $11^{\text {th }}$ century in Kashgar, a center of Islamo-Turkic culture during that time. ${ }^{33}$ Togan also mentioned

\footnotetext{
${ }^{26}$ Mehmed Fuad Köprülü, Türk edebiyati tarihi. Ed. and simplified by Orhan Koprülü - Nermin Pekin, (İstanbul: Ötüken Publications, 1980), 163.

27 Togan, "The Earliest Translation", 13.

${ }_{28}$ Togan, "The Earliest Translation", 1; and Eckmann, "Eastern Turkic Translations", 151.

29 İnan, Makaleler ve incelemeler, (Ankara: The Institution for the Turkish History Publications, 1991), 2/129-130.

30 İnan, Bir inceleme, 10.

31 Eckmann, "Eastern Turkic Translations", 151.

32 Eckmann, "Eastern Turkic Translations", 151.

33 Eckmann, "Eastern Turkic Translations", 151.
} 
that this manuscript drew also on the original copy which was produced simultaneously with the Persian translation of al-Ṭabarîs commentary in the second half of the $10^{\text {th }}$ century. ${ }^{34}$ Togan further conducted a comparative textual study of early Persian translations and Turkish translations and showed the close relationship between the two traditions, and demonstrated how the latter was drawn on the former. ${ }^{35}$

Another manuscript in this category of the Turkic translation of the Qur'ān, or, more precisely, in which Turkic translation is included along with a Persian translation, is preserved in John Rylands Library in Manchester (England) as Rylands Arabic mss. 25-38. ${ }^{36}$ This is an immense, yet incomplete translation and it contains an interlinear Persian translation between the Arabic text of the Qur'àn and the interlinear Turkish translation. ${ }^{37}$ The manuscript consists of 14 volumes, three lines per page. The repetitious character of the Qurān can make up, to a great extent, for the incomplete parts. ${ }^{38}$ Togan stated that this copy could be dated to the $14^{\text {th }}$ century, ${ }^{39}$ which Eckmann agreed with, and further added that instances where the characteristics of the $12^{\text {th }}-13^{\text {th }}$ centuries Qarakhānid Turkic were not infrequent. ${ }^{40}$ Eckmann, in a separate article devoted to the study of this manuscript, studied the relationship between the Arabic text of the Qur'ann, Persian translation, and this Turkic translation. His study culminated in establishing various instances where Turkic translation complied with only the Arabic text of the Qur'àn, or only the Persian translation of the Arabic text, or both the Arabic text of the Qur'ann and the Persian translation of it, as well as instances where the Turkish translation differed from both the Arabic text of the Qurān and its Persian translation. ${ }^{41} \mathrm{He}$ later noted that in majority of the cases the Turkish translation complies with the Persian translation. However, he further added, no conclusive decision can be reached from the comparison of the three texts as to which of the two, the Arabic or the Persian translation, the Turkish translation drew on, and it is not unlikely that other Persian and Turkish translations were also used and

\footnotetext{
${ }_{34}$ Togan, “The Earliest Translation”, 13.

35 Togan, "The Earliest Translation", 4-13.

36 Eckmann, "The Earliest Translations", 153.

37 Eckmann, “The Earliest Translations", 153.

38 Eckmann, "The Earliest Translations", 154.

39 Togan, “The Earliest Translation”, 2.

40 Eckmann, "Doğu Türkçesinde bir Kur’an çevirisi (Rylands nüshası)” Belleten, Türk Dili Araştırmaları Yillı̆̆ı. (1967), 53-69. 58.

${ }^{41}$ Eckmann, "Doğu Türkçesinde", 55-58.
} 
the copyist simply wrote the Persian and Turkish glosses under the Arabic words without caring much about their compliance with each other. ${ }^{42}$

Another manuscript of the Turkic interlinear translation of the Qur'ān is preserved in Süleymaniye Library, Hekimoğlu Ali Paşa Camii no: 2. The number of folios is 588 , each folio containing nine lines. It is a complete translation with a very little commentary-like note. ${ }^{43}$ The date of the copy is given as 1363 with no name of an author. Inan argued that this manuscript was younger than the Anonymous and the Leningrad manuscripts, and its philological characteristics point to the possibility that it drew on an original that was composed in the $11^{\text {th }}$ century. ${ }^{44}$ It was written in the Khorezmian Turkic dialect, and the various instances where the heretorfore mentioned Persian-influenced translations which were Turkicized in this manuscript are pointed out by Togan ${ }^{45} \mathrm{~A}$ critical study of this manuscript was undertaken by Gülden Sağol and her study was published by Harvard University Press in an edition that includes an introduction, the text, a glossary, and the facsimile edition. ${ }^{46}$

\section{TRANSLATIONS AND COMMENTARIES OF THE QUR' N DURING THE SALJUQID AND OTTOMAN ERA}

No record of Turkish translation or commentary of the Qurān can be detected from the Saljuqid dynasty. It seems that the Anatolian Saljuqs continued the tradition of the greater Saljuqid dynasty of the Iranian lands in preferring Arabic and Persian over their national language as the language of arts and sciences. ${ }^{47}$ Turkish translations and commentaries of the Qur'an or parts of it were produced during the era of the Anatolian principalities which followed the fall of the Saljuqid dynasty and preceded the Ottoman dynasty. Yet these translations that were produced during the era of principalities are limited to a number of individual chapters of the Qurān, and the translations and commentaries of the whole Qurān would only come out after the rise of the Ottomans in Anatolia by the $14^{\text {th }}$ century. ${ }^{48}$

It appears that the commentary in Turkish of individual chapters of the

\footnotetext{
${ }^{42}$ Eckmann, "The Earliest Translation”, 153-154.

${ }^{43}$ Eckmann, "The Earliest Translation", 153-154.

44 İnan, "Bir İnceleme", 11.

45 Togan, "The Earliest Translation", 16.

${ }^{46}$ Gülden Sağol, An Interlinear Translation of the Qur'an into Khwarazm Turkish: Introduction, Text, Glossary and Facsimile. Old Turkish and Persian Interlinear Qur'an Translations 1, 5 vols. (Harvard University Press, 1993).

47 İnan, "Bir inceleme", 14.

48 İnan, "Bir inceleme", 14.
} 
Qur'ān or their translations from Arabic commentaries continued during the early years of the Ottoman dynasty. One such work that can be dated as the earliest is the commentary on chapter 67 of the Qur'ān, al-Mulk, written by an unknown author in 1333 and dedicated to Sulaymān Bey (d.1357), son of Orkhān Ġāzī (Orhan Gazi) (r. 1324-1361). ${ }^{49}$ The famous scholar of Orhan Gazi’s dynasty, Muṣtafā Ibn Muḥammad Anqarawī wrote a commentary on chapter 36 of the Qur'ān, Ya-Sin, which was also dedicated to Sulaymān Bey. The latter appears to be the patron of Qur'anic commentaries in Turkish since there is at least one more partial Qur'anic commentary in Turkish that was dedicated to him and was authored by Anqarawi.$^{50} \mathrm{We}$ do not know why the commentaries of individual chapters rather than the whole Qur'ān were the interest of the time; however, we may incline to presume that the "Faḍ̂a'il al-Qur'an" (the virtues/merits of the Qur'ān) and the "Fad̂a'il al-suwar" (the virtues/merits of the sūras) literature must have enjoyed greater significance among the early Ottomans. Consequently, the Qur'anic commentary activities concentrated only on particular chapters of the Qurān. Pietistic concerns were also the reason for the production of commentaries on individual chapters of the Qur'an. One of these commentaries in Turkish is on chapter 112 of the Qur'ān, al-Ikhlās, composed by Muhyiddīn Niksārī (d. 1495). The author tells us that the praying public asked him to write a commentary on chapter 112 in Turkish so that they may better contemplate during their prayers. ${ }^{51}$

Turkish commentaries of the whole Qurān began to emerge only by the turn of the $15^{\text {th }}$ century. However, this tradition started as translations of earlier commentaries written in Arabic. The earliest translation of this type was probably Abū al-Layth al-Samarqandī's (d.983) Tafsīr al-Qur'ān or Tafsìr Abù al-Layth al-Samarqandī. This translation is reported to have been authored by three near-contemporary early Ottoman scholars: Aḥmed-i Dā‘̄ (d. 1427) ${ }^{52}$; Mūsā Iznikī (d. 1435) ${ }^{53}$; and Ibn Arabshāh (d. 1450). ${ }^{54}$ Most of the modern Turkish scholars seem to have overlooked the copy that is attributed to Aḥmed-i $D^{-}{ }^{-} \overline{1}$ and indicate that the latter two translated Abù

\footnotetext{
${ }^{49}$ Hidayet Aydar, "Dini bilimler, Osmanlılarda tefsir çalışmaları, 547.

50 Aydar, "Dini bilimler", 547.

51 Aydar, "Dini bilimler", 547.

52 Günay Kut, "Ahmed-i Dai”, Türkiye Diyanet Vakfı İslâm Ansiklopedisi, (Ankara: TDV Yayınları, 1989), 2/56-58.

${ }_{53}$ M. Kamil Yaşaroğlu, "Musa Izniki”, Türkiye Diyanet Vakfı İslâm Ansiklopedisi, (Ankara: TDV Yayınları, 2006), 31/218-219.

54 Abdülkadir Yuvalı, "Ibn Arabşah", Türkiye Diyanet Vakfı İslâm Ansiklopedisi, (Ankara: TDV Yayınları, 1999), 19/314-315.
} 
al-Layth's Qur'anic commentary separately. ${ }^{55}$ No modern research indicates what the title of Ibn Arabshāh's translation was, but most of the copies of Iznikī's translations are titled as Enfesu'l-cevāhīr/Anfas al-jawāhir and a few of them are titled as Tercüme-i Tefsīr-i Ebī'l-Leys es-Semerkandī. ${ }^{56}$ Ziya Demir, in his unpublished dissertation, stated that Iznikī actually translated Lubāb al-ta'wīl fì ma'ānì al-Tanzīl of al-Khāzin al-Baghdādī (d. 1340) and gave it the title of Enfesu'l-cevāhìr, and that the translation of Abu alLayth's commentary was wrongly attributed to him. ${ }^{57}$ Demir also surveyed the copies that have been attributed to Ibn Arabshāh and concluded that this translation was authored by Aḥmed-i Dā'ī in reality. Yet, for unknown reasons, it was attributed to Iznikī and Arabshāh as well. ${ }^{58}$ Macit Yaşaroğlu added that the first facsimile edition of Ebu'l-Leys es-Semerkandī Tefsirinin Tercümesi, modern turkicized version of which was published in 1993. It was also dubiously attributed to Musa Izniki ${ }^{59}$ Furthermore, while some researchers asserted that the Tercume-i Ebìl-Leys and the Enfesu'l-cevāhìr were the same and identical, other researchers indicated that the latter was an independent Turkish commentary which, to a great degree, drew on both Abū al-Layth and al-Baghdādīss commentaries. ${ }^{60}$ We do not have any information on who the dedicatee was of the translation attributed to Ibn 'Arabshāh, but Susan Gunasti, in her recent survey on the topic, mentioned a more detailed study on him and determined that what was attributed to Ibn 'Arabshāh was actually authored by Mūsā Iznikī. ${ }^{61}$

Modern research on this topic is mired in ambiguities and some more detailed studies are needed. While it is not so vital, considering the purpose of our study, to determine the authorship of these translations, we would like to point out that it is not at all improbable for more than one author to undertake the translation of Abū al-Layth's commentary. The early $15^{\text {th }}$ century, during which these translations were produced was a period of chaos and turmoil in Anatolia where several principalities vied for supremacy. Patronage of religious scholars and scholarly heritage was

\footnotetext{
55 Aydar, "Dini bilimler, Osmanlılarda", 61.

56 Aydar, “Türklerde Kur’an çalışmaları” Istanbul Üniversitesi İlahiyat Fakültesi Dergisi 1 (1999), 159235. 172., also see Ahmed Topaloğlu, "Kur’an-i Kerim’in ilk Türkçe tercümeleri ve Cevahiru'l-esdaf”. Turk Dünyasi Arastimalari 27, (1983), 58-66. 61, and also Yaşaroğlu, Kronolojik bibliyografi, 129.

57 Aydar, "Dini bilimler", 548.

58 Aydar, "Dini bilimler", 548.

59 Yaşaroğlu, "Musa Izniki” 31/218-219.

60 Yaşaroğlu, "Musa Izniki” 31/218-219.

${ }^{61}$ Susan Gunasti, "Political Patronage and the Writing of Qur'ān Commentaries Among the Ottoman Turks” Journal of Islamic Studies (2013), 1-23, 5.
} 
one of the main propagandistic tools that the heads of these principalities could appropriate in order to bolster support and prestige among their followers. Similarly, scholars needed to produce compositions in order to receive patronage. Based on the preceding accounts, therfore, we cannot exclude the possibility that a single work could have been commissioned for translation to various authors by different princes who, at the time, were vying for supremacy in Anatolian lands and were projecting themselves not only as protectors of inhabitants in their lands, but also as the promulgators and preservers of scholarly religious heritage to their subject people as well as the subject people of other principalities. Or, similarly, different princes commissioned different authors to have different tafsir works or other literary works, translated. A recent study demonstrated, in the example of Mușannifak (d. 1470), that some authors would compose a work and dedicate it to their patron with whom they sought protection and refuge, but upon the failure of that patron prince, the author would then seek the patronage of another prince, rewrite his work, and rededicate it to his new patron. Mușannifak first composed his commentary on the introductory verses of the Mathnawi of Rumi (d. 1274), and dedicated it to prince Ibrāhīm of the Qaramānid principality. When Meḥmed II conquered the Qaramānid lands, Mușānnifak moved to Ottoman court, composed a tafsīr work and not only did he then dedicate it to Mehmed II, his new patron, but he also went on a tirade against the Qaramānids whose lands he now viewed as "a heap of ruins and a perch for owls". 62

Based on the translations of Abū al-Layth's commentary, Abdülkadir Inan asserted that the translation and commentary of the Qur'ān in Anatolia was imported from Central Asia. ${ }^{63}$ We are not certain if this tradition can more concisely be termed either as Central Asian tradition or Eastern tradition? Unfortunately, no further elaboration on this tradition is offered by İnan. Susan Gunasti, in a recent article on the Qur'an commentaries of the Ottoman Turks, argued that tafsir endeavors by them were dominated during at least the $15^{\text {th }}$ century by "Samarqandi tradition", but in later centuries these endeavors were overtaken by the "madrasa exegetical tradition" which initially favored the al-Zamakhsharī (d.1144) tradition but later quickly gave way to al-Bayḍāwī (d. 1286) tradition. ${ }^{64}$ Other studies,

\footnotetext{
${ }^{62}$ Başkan, "Siyasi mekan değişikliğinin” 119-121.

63 İnan, Kur'ân-ı Kerîm'in Türkçe tercemeleri, 16.

${ }^{64}$ Gunasti, "Political Patronage", 1-23.
} 
however, demonstrated that her observations are untenable, vague, and more internal evidence from within these commentaries are needed. ${ }^{65}$

Catalogue surveys of Istanbul libraries indicate that there are numerous copies of this translation in manuscript form. A digital facsimile of Aḥmed-i Dāîss translation in an incomplete form, about 64 folios, is in our possession. ${ }^{66} \mathrm{~A}$ brief survey of this fragment reveals that there is a versified exordium in the beginning that was penned by the translator himself. In these introductory verses, the author presents a lengthy praise to God and the Prophet Muhammad, followed by the reason for which the author wrote his translation. The commentary on the Isti'ädha/Ta'wi dha ( $a^{\prime} \bar{u} d h$ bi'llāh min al-shaytạn al-rajīm, a formulaic prayer intended to dispel the evils that may be engendered by Devil, evil spirits, etc.) and the Basmala is probably the author's own contribution to Abū al-Layth's commentary. Based on the added commentary-like expressions in the translation, Ismail Hakkı Ertaylan, who surveyed the philological aspect of this translation, stated that it was more like an independent commentary which, to a great degree, drew on Abū al-Layth's commentary. ${ }^{67}$

There circulates within the Islamic book stores a Qur'anic commentary titled Baḥr al-'ulūm and attributed to Abū al-Layth al-Samarqandī. Our preliminary comparative study of Bahr al- 'ulüm and one of the translations of Abū al-Layth's commentary into Old Anatolian Turkish revealed that there are several differences between the two works. Ahmed-i Dāe $\bar{i}$, one of the known translators of Abū al-Layth's commentary, indicates that the latter's commentary was titled Tafsìr al-Qurān al- 'azīim wa kalamih al-qadìm and not Baḥr al- 'ulüm. ${ }^{68} \mathrm{Da}^{-}{ }^{e ̂}$ 's translation includes several insertions and variant traditions that are not found in Baḥr al-'ulüm. For example, Dā'ì devotes three pages interpreting the Ta' wìdha which cannot be found in Baḥr al-' ulüm. ${ }^{69}$ We, therefore, need to note here that it should still be ascertained whether the Baḥr al-ulūm belongs to Abū al-Layth al-Samarqandī or to 'Alä al-Dīn al-Samarqandī (d. 1456) that came from Central Asia and settled in Anatolia. Other modern studies thus seems to have demonstrated

\footnotetext{
$\overline{{ }^{65}}$ For a detailed discussion on Gunasti's thesis, see Halil Simsek "The Missing Link in the History of Qur'anic Commentary: The Ottoman Period and the Qur'anic Commentary of Ebussuud/Abū al-Su'ūd al-'Imādī (d. 1574 CE), Irshād al-'aql al-salīm ilā mazāyā al-Kitāb al-Karìm”" (Toronto: University of Toronto, Unpublished PhD dissertation, 2018), 77-80.

66 Süleymaniye Library, Fatih No: 631.

67 Aydar, "Dini bilimler", 547.

68 MS Fatih 631, 5.

${ }^{69}$ MS Fatih 631, 6-12.
} 
that the Bahr al-ulūm has wrongly been attributed to Abū al-Layth, and it perhaps more correctly belongs to 'Alā al-Dīn al-Samarqandī. ${ }^{70}$

One cannot help wonder why it was the commentary of Abū al-Layth that the early Ottoman scholars decided to translate from among the many other commentaries which figured more prominently within the Ottoman religious learning such as al-Bayḍāwīs (d. 1286) Anwār al-Tanzīl, al-Rāzīss (d. 1210) Mafātih al-ghayb, and al-Nasafîss (d.1310) Medärik al-Tanzìl? The answer probably lies in the fact that Abū al-Layth was believed to be of Turkic origin, and that his commentary was relatively short and concise. It also would fit the category of madrasa style commentaries. Besides, he was a Hanifite and a Māturidite which would make his commentary in compliance with the creedal doctrine of the latter and the legal doctrine of the former schools of thought. Moreover, several Ottoman scholars were either educated in the religious colleges of Central Asia or traveled to this region for the purpose of gaining knowledge during the early decades of the Ottoman dynasty. ${ }^{71}$ Thus, Ibn Arabshāh, one of the attested translators of this commentary completed his education in the religious colleges of Samarqand. ${ }^{72}$ Furthermore, Richard Hartman noted that despite the insignificance of Abū al-Layth's commentary among the Arabs, it enjoyed importance among the Turks. This resulted from the fact, Hartman reasoned, that the tradition of translation and commentary of the Quran in Anatolia was imported from Central Asia. ${ }^{73}$

The versified exordium of Dāis's translation has a section where the author mentions how he came to write his translation. He states that although he thought of himself unfit for such an endeavor, he, at the same time, believed that God is He Who changes inefficiency to success. He also informs us that God showed him a sign, implying that His grace was made shelter for him and that, relying on Divine assistance, he was to start writing his book. He also stated that he had two purposes in his translation. Firstly, he wanted to compose a translation of God's word enriched with prophetic traditions and words of wisdom by sufis and scholars. Thus, may whoever reads it pray to God for him. Secondly, he was asked, in the presence of the

\footnotetext{
${ }^{70}$ See, Simsek, “The Missing Link”, 72-73; also İshak Yazıc1, "Bahru'l-'ulûm”, Türkiye Diyanet Vakfl İslâm Ansiklopedisi (Ankara: TDV Yayınları, 1991), 4/517-518.

71 Aydar, "Dini bilimler", 548.

72 Aydar, "Dini bilimler", 548.

73 İnan, Bir inceleme, 16.
} 
Amir, to write a translation with which the Amīr would keep close company. $^{74}$

Another commentary-like translation of the Qur'ān written in Ottoman Anatolia is titled Jawāhir al-așdäf. The author of this translation is unknown and modern researchers proved the date of its composition as the early years of the $15^{\text {th }}$ century. ${ }^{75}$ The author follows the individual verses with their meanings in Turkish and occasionally elaborates further to include the occasions of revelation, histories of earlier prophets and their communities, and legal rulings derived from the verses. ${ }^{76}$ In contrast to the interlinear translations, this commentary-like translation presents the translation, as well as the extra interpretive explanations, of a given verse, in full sentences, complying considerably with the Turkish syntax; yet the influence of the earlier interlinear word by word translations therein can be easily detected. ${ }^{77}$ There are innumerous copies of this translation in manuscript form, which led Ahmed Topaloğlu to argue that this commentarylike translation was more widely used and in circulation than the translation of Abū al-Layth's commentary ${ }^{78}$ Compared to Abū al-Layth's commentary, Jawāhir al-așdäf is much shorter and more concise, which could be viewed as another reason for its wide usage and circulation among the madrasa students and the general public. ${ }^{79}$ The date of the composition and its dedicatee can only be inferred from internal implications. The author, in the introduction, makes praising reference to Isfendiyar b. Bāyezīd Khān and his son Ibrāhīm Bey Chalabī, both of whom are the late heirs to the $15^{\text {th }}$ century Candaroğlu principality in the environs of Kastomonu, a northern coastal region in Anatolia. ${ }^{80}$ Having sided with Timur against Bāyezīd I (r. 1389-1402), Isfendiyar Bey was able to remain as the ruler over his principality until 1417 and it follows that this work must have been completed in between 1402 and 1417. ${ }^{81}$ Thus, while Ananias Zajaczkowski believed it to have been written in 1404, ${ }^{82} \mathrm{Cl}$ [aude] Huart stated to have possessed in his personal collection a partial manuscript copy of this commentary which he

\footnotetext{
${ }^{74}$ We do not have any information as to who was to decide which commentary to be translated, the Amir or the translator himself?

75 Topaloğlu, "İlk Türkçe tercümeler", 65.

76 Topaloğlu, "İlk Türkce tercümeler", 63.

77 Topaloğlu, "İlk Türkce tercümeler", 63.

78 Topaloğlu, "İlk Türkce tercümeler", 64.

79 Topaloğlu, "İlk Türkce tercümeler", 64.

80 Topaloğlu, "İlk Türkce tercümeler", 64.

${ }_{81}$ Topaloğlu, "İlk Türkce tercümeler", 64 .

82 İnan, “Bir inceleme”, 16.
} 
thought was written in a dialect which was peculiar to the region of Kastomonu and its environs during the early $15^{\text {th }}$ century. ${ }^{83}$ No modern research indicates anything about the sources that the author might have used.

Another interlinear translation of the Qurān was authored during the early $15^{\text {th }}$ century in Ottoman Anatolia. Ahmed Topaloğlu wrote his dissertation on what he believed to be the oldest copy of the extant manuscripts of this translation. According to its colophon, it was completed in 1424 by Muhammad b. Hamza, whose identity is not easily determinable. Topaloğlu inclined to believe that he is the same person as Shams al-Din Muhammad b. Hamza al-Fanārì (d. $1431 \mathrm{CE}$ ), the first shaykh al-Isläm of the Ottoman dynasty, who migrated from Central Asia to Anatolia when he was 18 years old. ${ }^{84}$ The whole translation is in 290 folios written at forty-five degree angle to the left under each line of the Arabic text of the Qurān..$^{85}$ Interpretive explanations are abundantly scattered around the margins of the pages and in between the lines where space permitted. ${ }^{86}$ Both the Arabic text and the translation are fully vocalized, and at the end of the translation, there is a sixty-five verse invocation that is believed to be a later addition. ${ }^{87}$ As a characteristic of interlinear Qurān translations, the word order is not well observed, however, the translator's brilliant use of Turkish participles and conjunctives mitigate the effect of awkward sentence constructions. ${ }^{88}$ In several instances, word by word translation order is overlooked, such as adjectival clause constructions where the translation is rendered in compliance with the Ottoman/Anatolian Turkish syntax..$^{89}$

Quranic commentary in Turkish language continued during the succeeding centuries until the establishment of modern Turkish Republic. However, it appears that all the commentaries in Anatolian and Ottoman Turkish between the $16^{\text {th }}$ and $19^{\text {th }}$ centuries are the translations of earlier Arabic or Persian commentaries, and independent Qurān commentaries in Turkish would not be produced until the early $20^{\text {th }}$ century.

One of these translated commentaries is titled Aynil-hayāt and preserved in 'Azīz Maḥmūd Hudāī Library as no: 48. This manuscript sur-

\footnotetext{
${ }_{83}$ Yaşaroğlu, Kronolojik bibliyografi, 126.

${ }^{84}$ Topaloğlu, Muhammad Bin Hamza, XV. Yüzyıl başlarında yapılmış satırarası Kur'an tercümesi. [Muhammad Ibn Hamza, an early $15^{\text {th }}$ century Interlinear Translation of the Qur'an] 2 vols. (Istanbul: Milli Egitim Basimevi, 1976). 1/15-16.

85 Topaloğlu, Muhammad Bin Hamza, 19.

86 Topaloğlu, Muhammad Bin Hamza, 20.

87 Topaloğlu, Muhammad Bin Hamza, 20.

88 Topaloğlu, Muhammad Bin Hamza, 21.

${ }^{89}$ Topaloğlu, Muhammad Bin Hamza, 21-22.
} 
vived in an incomplete copy, starting from the middle of chapter 18 of the Qurān and ending with a colophon recording the date of copy as 1559 by Muḥammad b. Hasan Eknafī..$^{90}$ Kātib Chalabī recorded this translation as 'Ayni'l-ḥayāt fì tafsìr Najm al-Dìn al-Rāzī. ${ }^{91}$

Another translated commentary is "Terceme-i tefsīri'l-Mavāhib'l-Aliyye" which was translated circa 1573 by Ebu'l-Faḍl el-Bitlisī (d. 1574). ${ }^{92}$ It is the translation of Husayn Ibn 'Alī al-Kāshifīs (1514) Persian commentary "Al-Mavāhib al-aliyya." This copy survived in a single and incomplete manuscript which is preserved in the Library of Istanbul University as no: 1195. The extant copy of the first volume of this translation includes an invocation and a foreword authored by the translator, and the translated commentary up to chapter 18, al-Kahf. ${ }^{93}$ Al-Kāshifî̀s Persian commentary was also translated separately later by Ferruh Ismāi îl Efendì (d.1840), with additions and modifications taken from al-Zamakhsharī, al-Bayḍāwī, and others. ${ }^{94}$ Ferruh Ismāîl's translation was published several times under the title of Tafsìru'l-mevākib. ${ }^{95}$

In 1684, Aḥmed Șālih Ibn 'Abdullāh, a preacher in Baghdād, was asked by the vizier Ibrahim Pasha to translate the whole Qurān into Turkish. ${ }^{96}$ Within one year Aḥmed Șālih completed his translation, drawing mainly on Anwār al-Tanzīl of al-Bayḍāwī, al-Mavāhib al-'aliyya of al-Kāshifì, hence it is titled as Zubde-i āsār al-Mavāhib ve'l-envār, as well as other renowned commentaries. ${ }^{97}$ Several complete manuscript copies of this commentary in two volumes are preserved in Istanbul Libraries, and a lithography edition of it was located in Süleymaniye Library, Nāfiz Pasha section as no: $61 .{ }^{98}$

Probably four years later in 1698, Khị̣r Ibn 'Abd al-Raḥmān al-Azdīs (d. 773/1371) al-Tibyān fì tafsīr al-Qur'ān was translated by Muhammad b. Hamza al-Dabbāgh (d.1699) of 'Ayntāb as Tefsīr-i Tibyān. ${ }^{99}$ We are told in the prologue that the author was educated in 'Ayntāb and Sivas and then migrated to Istanbul where he was introduced by the shaykh al-Isläm to the

\footnotetext{
90 Yaşaroğlu, Kronolojik bibliyografi, 135.

91 Yașaroğlu, Kronolojik bibliyografi, 135.

${ }_{92}$ Yaşaroğlu, Kronolojik bibliyografi, 133.

${ }_{93}$ Yaşaroğlu, Kronolojik bibliyografi, 133.

94 Aydar, "Dini bilimler", 548.

95 Yaşaroğlu, Kronolojik bibliyofrafi, 143-145.

96 Aydar, "Turkler'de Kur'an”, 172.

97 Aydar, “Turkler'de Kur'an”, 172.

98 Yaşaroğlu, Kronolojik bibliyografi, 146.

99 Aydar, “Turkler'de Kur'an” 173.
} 
sultan, after which he wrote two copies and presented one to the sultan and the other was made available to the public. ${ }^{100}$ Several manuscripts survived and are preserved in various Istanbul libraries (Veliyyuddin no: 129), and at least three printed editions in Arabic/Ottoman script are located. ${ }^{101}$

Ottoman tradition of Qur'anic commentaries is not limited to translations or commentaries in Turkish, and in fact, the most famous commentaries produced by the Ottomans were written in Arabic. Teaching the Arabic language was the first and foremost aim of the religious colleges whereby the students were enabled to work with the primary sources. Until the second half of the $15^{\text {th }}$ century, Ottoman education centers of Islamic sciences, madrasas, were in a nascent state and could not compete with those of Central Asia, Iran, and the Arab lands. Therefore, during the first two centuries of the dynasty, the teachers of these religious colleges were supplied from scholars who either migrated from other lands or were educated in the famous religious centers of Central Asia, Iran and the Arab lands. ${ }^{102}$ Ottoman religious colleges would later produce their own scholars who could transmit religious knowledge in Turkish. However, Arabic language retained its status, probably due to the fact that a greater majority of the sources on which the religious instruction relied had not been translated into Turkish. Perhaps more importantly, it was also a political and strategic plan in that by keeping the Arabic language as the medium of religious instruction, the state would conform up to the standards of other religious education centers. Thus, the state establishment would grow more competitive with the surrounding Muslim power centers.

Several Ottoman scholars authored Qur'anic commentaries in Arabic and some of these commentaries were famed in all over the Muslim world and some others were not known even in the Ottoman madrasas. Two of the commentaries which have been renowned by the Muslim world are the commentary of Ebussuud Efendi/Abū al-Su'ūd al-'Imādī (d. 1574), titled Irshād al-'aql al-salìm ila mazāyā al-Kitāb al-Karīm, and the commentary of Ismāî̀l Hakkı Bursawī (d.1725), titled Rūḥ al-bayān fì tafsīr al-Qur'ān. Some modern studies assert that the former draws mainly on earlier commentaries of al-Zamakhsharī, al-Rāzī and al-Bayḍāwī as well as other commentaries. ${ }^{103}$ But other surveys demonstrate that the sources on which

\footnotetext{
${ }^{100}$ Yaşaroğlu, Kronolojik bibliyografi, 136.

${ }^{101}$ Yaşaroğlu, Kronolojik bibliyografi, 141.

${ }^{102}$ Aydar, "Dini bilimler", 538.

${ }^{103}$ Aydar, "Dini bilimler", 544.
} 
it drew are much broader and more varied than might previously be assumed. ${ }^{104}$ It is a product of thirty years not of an extensive research but of extremely occupied and distracted scholarly career of its author. The latter, on the other hand, is a multi-volume commentary of the Qurān written over twenty-one year period by a man who reached the khalifa position in the Jalwatiyya sufi order. Therefore, it is no surprise that his commentary received a general acceptance within the sufi circles. ${ }^{105}$ Unfortunately, no critical and analytical edition or study of most of the here-to-fore mentioned manuscripts have come out, and the few which have been conducted on some of them lack the standards of critical and analytical scholarship. Even the bibliographical account of the Quranic commentaries authored by Ottoman scholars is not near complete, and, to our dismay, some are even rather superficial. However, some recent attempts are promising and much more detailed studies await future scholars. ${ }^{106}$

\section{CONCLUSIONS}

We have begun surveying the earliest attempts of translating the Arabic text of the Qurān into Turkic languages. Our study demonstrated that the scholarly opinion varies about whether or not the first Turkic translations of the Qur'an can be dated as far back as the earliest translation of the commentary of al-Tabari into Persian. However, the scholarly opinion also seems to converge on the fact that all the early Central Asian Turkic translations of the Qurān drew on a now lost original which probably can be dated back as early as the 11th century. By contrast, the earliest surviving copy of such a translation, known as the "anonymous", can only be dated back to the 12th century, which was followed by other translations and commentary-like translations until the 16th century. Although most of these translations are the translations of the Qurān through Persian translations of it or are modelled after the Persian translations, direct translations of the Arabic text of the Qurān are not infrequent. Even though translations of parts of the Qurān are encountered during the Saljuqid and early Ottoman

\footnotetext{
${ }^{104}$ See Simsek, “The Missing Link”, 194-208.

${ }^{105}$ Aydar, "Dini bilimler", 545.

${ }^{106}$ For bio-bibliographical surveys see, Muhammed Abay "Osmanlı dönemi müfessirleri." (Bursa, Uludağ Üniversitesi, SBE., Unpublished MA thesis, 1992), and "Osmanlı döneminde yazılan tefsir ile ilgili eserler bibliyografisi” Divan: İlmi Araştırmalar 6, no. 1 (1999), 249-303; Ziya Demir, Osmanl müfessirleri ve tefsir çalışmaları: Kuruluştan X/XVI. asrın sonuna kadar. (Istanbul: Ensar Neşriyat, 2007); İshak Doğan, Osmanlı müfessirleri.( Istanbul: İz Yayıncılık, 2011).
} 
era, complete translations of the Qur'ān and/or earlier Qur'anic commentaries are witnessed in the Ottoman realm with the turn of the 15 th century. Perhaps the earliest such translation was the translation of the Qur'anic commentary attributed to Abū al-Layth al-Samarqandī. This translation is attested to have been authored by three different translators. Though the possibility that the translation of this commentary was commissioned by different princes and conducted by different figures is not unlikely, our survey led us to determine that it was originally translated by Ahmed-i Dāî but was wrongly attributed to others as well. Even though some modern researchers proposed various theses that the tradition of translation and commentary of the Qur'ān was imported from Central Asia, their formulations are rather vague and ambiguous and unsupported by internal evidence from within the translated works. These translations were followed by other translations throughout the 16 th and 17 th centuries. These were mainly the translations of Arabic and Persian commentaries of the Qurān. There have also been various attempts especially by numerous number of Ottoman scholars to produce complete and independent commentaries of the Qur'ān, but since many of these works remain in manuscript form, we do not even have a near-complete bibliograhic record. Few of these works have been accounted for, edited, published, and made available for scholarly surveys. The majority of the modern surveys conducted on them seems to be rather descriptive. Therefore, we would like to conclude that there is a wealth of translations and commentaries of the Qurān produced especially during the Ottoman era which await analytical and critical study.

\section{BIBLIOGRAPHY}

Abay, Muhammed. “Osmanlı dönemi müfessirleri”" Bursa: Uludă̆ Üniversitesi, SBE., Unpublished MA thesis, 1992.

Abay, Muhammed. "Osmanlı döneminde yazılan tefsir ile ilgili eserler bibliyografisi” Divan: İlmi Araştırmalar 6, no. 1 (1999), 249-303.

Aydar, Hidayet. “Türkler'de Kur’an çalışmaları.” İstanbul Üniversitesi İlahiyat Fakültesi Dergisi 1 (1999), 159-235.

Aydar, Hidayet. “Dini bilimler: Osmanlılar'da tefsir çalışmaları.” Yeni Türkiye Dergisi, special issue. 33 (2000), 535-550.

Barthold, W. “Orta Asyada İslam’ın intişar ettiği zamana ait bir abide.” Türkiyat Mecmuası (Istanbul), 2. Publications of the Turkish Institution in Istanbul Faculty of Arts, (1926), 69-84. 
Birnbaum, Eleazar. “On Some Turkish Interlinear Translations of the Koran.” Journal of Turkish Studies 14 (1990), 113-138.

Demir, Ziya. Osmanlı müfessirleri ve tefsir çalışmaları: Kuruluştan X/XVI. asrın sonuna kadar. Istanbul: Ensar Neşriyat, 2007.

Doğan, İshak. Osmanlı müfessirleri. Istanbul: İz Yayıncılık, 2011.

Eckmann, Janos. “Eastern Turkic Translations of the Koran." Studia Turcica, ed. L. Ligeti, Akademiai Kiado, Budapest: y.y. 1971, 149-159.

Eckmann, Janos. “Doğu Türkçe’sinde bir Kur’an çevirisi (Ryland Nüshası).” Türk Dili Araştırmaları Yıllı̆̆ı, Belleten 266, b.y.: Publication of the Turkish Language Institution, (1967), 51-69.

Hamidullah, Muhammad - Macit Yaşaroglu. Kuran Tarihi: Kur'an-ı Kerim’in Türkçe terceme ve tefsirleri bibliyografisi. Ankara: Diyanet İşleri Başkanlığı Yayınlar1, 1991.

İnan, Abdulkadir. Kur'an-ı Kerim’in Türkçe tercemeleri üzerinde bir inceleme. Ankara: Diyanet İşleri Başkanlığı Yayınları, 1961.

İnan, Abdulkadir. Makaleler ve Incelemeler. 2 vols. Ankara: Türk Tarih Kurumu Yayınları, 1991.

Köprülü, M. Fuad, Türk Edebiyatı Tarihi. Ed. and simplified in modern Turkish by Orhan F. Köprülü - Nermin Pekin. İstanbul: Ötüken Publications, 1980.

Kut, Günay. “Ahmed-i Dai”. Türkiye Diyanet Vakfi İlâm Ansiklopedisi. 2/56-58. Ankara: TDV Yayınları, 1989.

Sağol, Gülden, An Interlinear Translation of the Qur'an into Khwarazm Turkish: Introduction, Text, Glossary and Facsimile. Old Turkish and Persian Interlinear Qur’ān Translations 1, 5 vols. Cambridge: Harvard University Press, 1993.

Simsek, Halil. “The Missing Link in the History of Qur'anic Commentary: The Ottoman Period and the Qur'anic Commentary of

Ebussuud/Abū al-Su'ūd al-'Imādī (d. 1574) Irshād al-'aql al-salìm ilā mazāyā alKitāb al-Karīm". Toronto: University of Toronto, Unpublished PhD dissertation, 2018.

Togan, Z. Velidi. “The Earliest Translation of the Qur'an into Turkish.” 4 Publications of the Faculty of Letters, İstanbul: Istanbul University, 1964, 1-19.

Topaloğlu, Ahmet. Muhammad Bin Hamza , XV. Yüzyıl Başlarında Yapılmış Satırarası Kur'an tercümesi. 2 vols. Istanbul: Milli Eğitim Basımevi, 1976.

Topaloğlu, Ahmet. “Kur’an-1 Kerim’in Ilk Türkçe Tercümeleri ve Cevahiru’l-Asdaf.” Türk Dünyasi Araştırmaları 27 (December 1983), 58-66.

Wilson, M. Brett. The Qurān After Babel: Translating and Printing the Qur'ān in 
Late Ottoman and Modern Turkey. S. Caroline: Duke University, Unpublished Ph.D dissertation, 2009.

Yaşaroğlu, M. Kamil. "Musa Izniki”. Türkiye Diyanet Vakfi İslâm Ansiklopedisi. 31/218-219. Ankara: TDV Yayınları, 2006.

Yazıc1, İshak. "Bahru'l-'ulûm”. Türkiye Diyanet Vakfı İslâm Ansiklopedisi. 4/517518. Ankara: TDV Yayınları, 1991.

Yıldız, Sakıp. Fatih'in Hocası Molla Gürani ve Tefsiri. İstanbul, Sahaflar Kitap Sarayı, N.D.

Yuvalı, Abdülkadir. "Ibn Arabşah". Türkiye Diyanet Vakfi İslâm Ansiklopedisi. 19/314-315. Ankara: TDV Yayınları, 1999. 